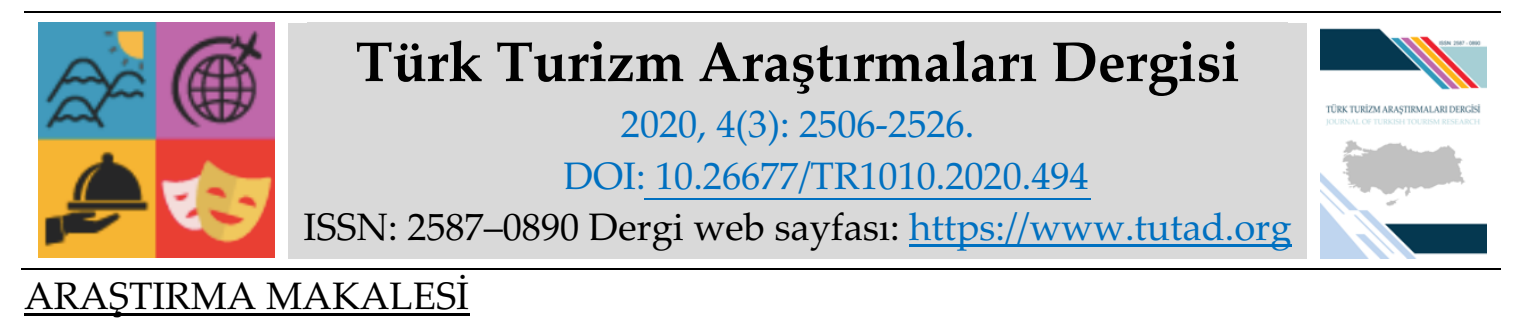

\title{
Gastronomi ve Mutfak Sanatları Bölümü Akademik Personelinin Eğitim Profili: Devlet Üniversiteleri Üzerine Bir Araştırma
}

Bahar DEVECİ, Doktora Öğrencisi, Balıkesir Üniversitesi, Sosyal Bilimler Enstitüsü, Balıkesir, e-posta: bahar.dvc@gmail.com

ORCID: https://orcid.org/0000-0001-6795-2477

Dr. Öğr. Üyesi Bilal DEVEĊ, Kırklareli Üniversitesi, Turizm Fakültesi, Kırklareli, e-posta: bilaldeveci@gmail.com

ORCID: https://orcid.org/0000-0003-3125-6917

Prof. Dr. Yusuf AYMANKUY, Balıkesir Üniversitesi, Turizm Fakültesi, Balıkesir, e-posta: aymankuy@balikesir.edu.tr ORCID: https://orcid.org/0000-0001-7332-3271

Doç. Dr. Şimal AYMANKUY, Balıkesir Üniversitesi, Turizm Fakültesi, Balıkesir, e-posta: sayman@balikesir.edu.tr

ORCID: https://orcid.org/0000-0003-1033-6424

Öz

$\mathrm{Bu}$ çalışmanın amacı, gastronomi ve mutfak sanatları bölümündeki akademik personelin eğitim durumunun ortaya konulmasıdır. Bu amaç doğrultusunda akademik personellerin lisans, yüksek lisans, doktora eğitimleri ve unvanları incelenmiş ve raporlanmıştır. Araştırmada veri toplama tekniği olarak nitel araştırma yöntemlerinden olan betimsel nitelikli tarama modeli kullanılmıştır. Veriler, bölümlerin ve akademik personelin bilgilerinin bulunduğu internet siteleri taranarak elde edilmiştir. 40 kurum bünyesindeki gastronomi ve mutfak sanatları bölümünde toplam 243 akademik personel olduğu tespit edilmiştir. Bu akademik personelin yaklaşık \%40'ının doktor öğretim üyesi olduğu saptanmıştır. Gastronomi ve mutfak sanatları bölümünde bulunan akademik personelin çoğunluğunun turizm alanında eğitim derecesine sahip olduğu ortaya çıkarılmıştır. 243 akademik personelin 96'sının hem lisans hem yüksek lisans hem de doktora derecesinin turizm alanında olduğu belirlenmiştir. Tespit edilen bu sayı bölümde istihdam edilen akademik personelin yaklaşık \%40'ını oluşturmaktadır. Turizm alanından sonra en çok gıda mühendisliği eğitimi almış akademik personel olduğu tespit edilmiştir. Gıda mühendisliği eğitimi almış personelin toplam akademik personelin yaklaşık \%15'ini oluşturduğu belirlenmiştir. Gastronomi ve mutfak sanatları programında görev yapan diğer akademik personelin eğitim alanlarının oldukça çeşitli ve birbirinden farklı alanlar olduğu sonucuna ulaşılmıştır.

Anahtar Kelimeler: Eğitim, Turizm, Gastronomi ve Mutfak Sanatları, Akademik Personel.

Makale Gönderme Tarihi: 16.04 .2020

Makale Kabul Tarihi: 03.07.2020

Önerilen Atıf:

Deveci, B., Deveci, B., Aymankuy, Y. ve Aymankuy, Ş. (2020). Gastronomi ve Mutfak Sanatları Bölümü Akademik Personelinin Eğitim Profili: Devlet Üniversiteleri Üzerine Bir Araştırma, Türk Turizm Araştırmaları Dergisi, 4(3): 2506-2526.

(C) 2020 Türk Turizm Araştırmaları Dergisi. 


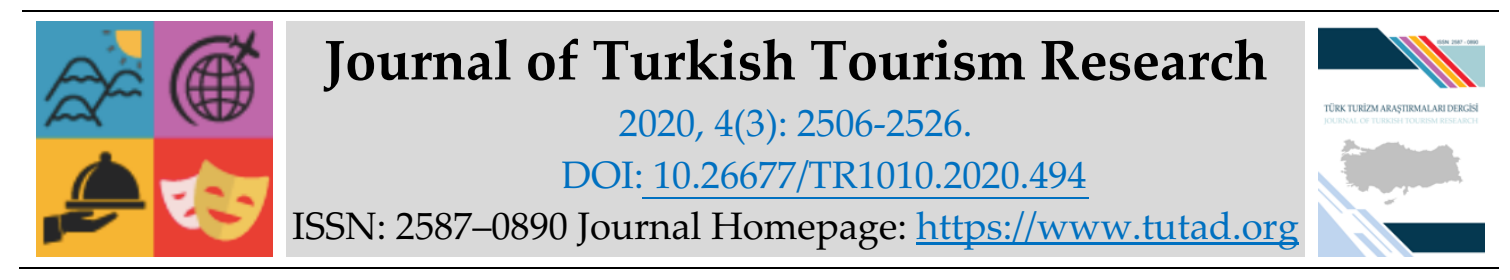

RESEARCH PAPE

\title{
Education Profile of Academic Staff in Gastronomy and Culinary Arts Department: An Investigation on State Universities
}

Bahar DEVECI, Ph.D. Student, Balıkesir University, Social Sciences Institute, Balıkesir, e-mail: bahar.dvc@gmail.com

ORCID: https://orcid.org/0000-0001-6795-2477

Assistant Prof. Dr. Bilal DEVECI, Kırklareli University, Faculty of Tourism, Kırklareli, e-mail: bilaldeveci@gmail.com

ORCID: https://orcid.org/0000-0003-3125-6917

Prof. Dr. Yusuf AYMANKUY, Balıkesir University, Faculty of Tourism, Balıkesir, e-mail: aymankuy@balikesir.edu.tr ORCID: https://orcid.org/0000-0001-7332-3271

Associate Prof. Dr. Şimal AYMANKUY, Balıkesir University, Faculty of Tourism, Balıkesir, e-mail: sayman@balikesir.edu.tr

ORCID: https://orcid.org/0000-0003-1033-6424

\begin{abstract}
The purpose of this study is to reveal the educational status of academic staff in the department of gastronomy and culinary arts. In accordance with this purpose, undergraduate, master, doctoral trainings and titles of academic staff was examined and reported. In this research, descriptive survey model, one of the qualitative research methods, was used as the data collection technique. The data was obtained by browsing the websites that contain the information of the departments and academic staff. It was determined that there are 243 academic staff in gastronomy and culinary arts department of 40 institutions. It was determined that approximately $40 \%$ of these academic staff is assistant professor. It was revealed that the majority of academic staff in the department of gastronomy and culinary arts have a degree in education in tourism. It was determined that 96 of 243 academic staff have undergraduate, master and doctorate degrees in tourism field. This determined number constitutes approximately $40 \%$ of the academic staff employed in the department. It was found that the number of academic staff who had education in food engineering has the highest number after tourism field. It was specified that the staff who had education in food engineering constitute $15 \%$ of the total academic staff. It was concluded that the education areas of the other academic staff working in the gastronomy and culinary arts program are quite diverse and different from each other.
\end{abstract}

Keywords: Education, Tourism, Gastronomy and Culinary Arts, Academic Staff.

Received: 16.04 .2020

Accepted: 03.07.2020

Suggested Citation:

Deveci, B., Deveci, B., Aymankuy, Y. and Aymankuy, Ş. (2020). Education Profile of Academic Staff in Gastronomy and Culinary Arts Department: An Investigation on State Universities, Journal of Turkish Tourism Research, 4(3): 2506-2526.

(C) 2020 Türk Turizm Araştırmaları Dergisi. 


\section{GİRIŞ}

Yeme ve içme insan yaşamının en temel ihtiyaçları arasında yer almaktadır (Murcott, 2019: 2). Yeme ve içmenin bilimsel ve sanatsal olarak incelenmesini sağlayanın da gastronomi bilimi olduğu ifade edilmektedir (Avcıkurt ve Sarığlan, 2019: 1). Gastronomi en genel ifade ile; yiyecek ve içeceklerin tarihsel gelişiminden itibaren tüm özelliklerini detaylı bir şekilde anlama, uygulama ve geliştirme çalışmalarını kapsayan bilim dalı olarak tanımlanmaktadır (Deveci, Türkmen ve Avcıkurt, 2013: 30). Gastronominin artık turizmle bütünleştiği, ülke tanıtımlarında önemli bir rol üstlendiği (Bucak ve Aracl, 2013: 207; Özkaya, Sünnetçioğlu ve Can, 2013: 14), turizm deneyiminin önemli bir parçası olduğu hatta bazı ziyaretçiler için temel motivasyon kaynağı olduğu ifade edilmektedir (McKercher, Okumuş ve Okumuş, 2008: 138). Turizmle bütünleşen gastronomi ilk başlarda turizm içinde bir faaliyet olarak ifade edilirken zaman geçtikçe gastronomi turizmi olarak ifade edilen bir turizm çeşidi olarak karşımıza çıkmıştır (Çuhadar ve Morçin, 2020: 93). Gastronomi turizmi; yiyecek ve içecekleri keşfetmek, tatmak ve unutulmaz bir gastronomi deneyimi yaşamak amacıyla yapılan seyahatler olarak tanımlanmaktadır (Kivela ve Crotts, 2005: 42).

Son zamanlarda özellikle kitle iletişim dünyasındaki mutfak şovları, şefler, mutfak yarışmaları, mutfak seyahatleri ile birlikte tüketicilerin yaşamları ve davranışları büyük ölçüde etkilenmiş (Gajic, 2015: 159) ve bu sayede talebin artmasıyla birlikte gastronomi turizmi oldukça popüler hale gelmiştir (Guzman ve Canizares, 2011: 63; Sünnetçioğlu, Yalçınkaya, Olcay ve Mercan, 2017: 346). Gastronomi turizminde yaşanan gelişmeler ile birlikte bu alanda çalışan nitelikli personele olan ihtiyacın arttığını söylemek mümkündür (Babaç ve Önçel, 2018: 283). Nitelikli personelin yetiştirilmesi hususunda da eğitim kurumları oldukça önem arz etmektedir (Akyurt, 2020: 56). Sektörün ihtiyaç duyduğu nitelikli personelin yetiştirilmesi için gastronomi eğitiminin sağlam temeller üzerine inşa edilmesi gerekmektedir (Yıldız ve Aslan, 2019: 1127). Bu noktada en önemli faktörlerden birinin eğitimciler olduğu ifade edilmektedir (Yazıcıŏglu ve Özata, 2018: 67). Gastronomi ve mutfak sanatları programında eğitim verecek olan akademik personelin alana ilişkin yeterli bilgiye, beceriye ve deneyime sahip olması beklenmektedir (Görkem ve Sevim, 2016: 980). Buradan hareketle, gastronomi ve mutfak sanatları programında eğitim veren akademik personelin eğitim durumlarının detaylı bir şekilde incelenmesinin önem arz ettiği düşünülmektedir. Yapılan bu çalışma ile de; Türkiye' deki gastronomi ve mutfak sanatları lisans programlarında görev yapan akademik personelin unvanlarının ve eğitim alanlarının incelenmesi, eğitim alanlarının bölüme uygunluğunun değerlendirilmesi ve ileride bu programlara yapılacak akademik personel atamasına ilişkin nasıl bir planlama yapılacağ hususunda bilgi verilmesi amaçlanmaktadır.

\section{KAVRAMSAL ÇERÇEVE}

Eğitim; sürdürülebilir sektörel yapıyı sağlayabilmek amacıyla her sektörün ihtiyaç duyduğu nitelikli işgücünü yetiştirmek için zorunlu bir ihtiyaç olarak kabul edilmektedir (Akyurt, 2020: 56). Bu doğrultuda da gastronomi eğitiminin temel amacl; sektörün ihtiyaç duyduğu bilgi ve yeteneğe sahip nitelikli işgücünü yetiştirmektir (Can ve Çiftçi, 2019: 2702). Gastronomi eğitimi ile; menü planlayabilen, yiyecek maliyetlerinin kontrolünü sağlayabilen, güvenli ve sağllklı gıdalar üretebilen, sektörde liderlik yapabilen (Cheng, Ogbeide ve Hamouz 2011: 17) aynı zamanda mutfak, restoran, cafe-bar, yiyecek ve içecek yönetimi (Ekincek, Göde, Önçel ve Yolal, 2017: 26,) yiyecek ve içecek tarihi, kültürü, toplumların yemek eğilimleri, yiyecek içecek işletmelerinin yönetim süreçleri (Santich, 2004: 23) gibi konularda bilgi sahibi olan işgörenler yetiştirebilmek hedeflenmektedir. Mutfak şeflerinin; hızlı hareket etme, dikkatli olma, verimli çalışma, sorumluluk sahibi olma, yaratıcı olma vb. gibi birtakım özelliklere sahip olması 
gerekmektedir. Kişi bu özelliklerin bazılarına doğuştan sahip olduğu gibi bazılarını da sonradan kazanabilmektedir. Bu noktada da gastronomi eğitimi sayesinde; doğuştan yeteneği olan kişilere sonradan kazandırılması gereken özellikler kazandırılarak eğitilmektedir. Nitelikli bir eğitim gören mutfak şeflerinin; özellikle işletmelerde maliyeti azaltma, karlılı̆̆ı arttırma, kaliteyi yükseltme vb. gibi katkıları bulunmaktadır (Birdir ve Kılıçhan, 2013: 630).

Gastronomi eğitiminin geçmişinin Antik Yunan ve Roma dönemlerine kadar dayandığından ve bu dönemlerde gastronomi eğitimi veren kurumların olduğundan bahsedilmektedir (Zopiatis, Theodosiou ve Constanti, 2014: 88). Gastronomi ile ilgili bilinen ilk kitabın ise 1. yüzyılda yazıldığı ifade edilmektedir. Ancak geçmişi bu kadar eskiye dayanan gastronomi eğitimi tam anlamıyla 18. yüzyılda gündeme gelmiştir. İlk olarak 18. yüzyılda İngiltere'de aş̧̧llk kursu açılmış ve bunu 19. yüzyılda Amerika'da ve Fransa'da açılan kurslar takip etmiştir. Fransa'da 1895 yılında açılan Le Gordon Bleu ve Amerika' da 1922 yılından beri aşçılık eğitimi veren Cornell Üniversitesi ilk mezun veren okullar arasında yer almaktadır (Öney, 2016: 196; Yazıcıoğlu ve Özata, 2017: 18; Kurnaz, Babür ve Kurnaz, 2018: 506).

Türkiye'de gastronomi eğitiminin ilk başlarda mutfak eğitimi olarak verilmeye başlandığı ifade edilmektedir. Mutfak eğitiminin 1960'lı yıllara kadar usta-çırak yöntemiyle verildiği (Bucak ve Yiğit, 2018: 813), 1960'lı yıllardan sonra ise; örgün eğitim ve yaygın eğitim olmak üzere iki şekilde verilmeye başlandığı bilinmektedir (Aymankuy ve Demirbulat, 2017: 225; Özdemir, Ak ve Önçel, 2019: 948; Can ve Çiftçi, 2019: 2702). Örgün eğitim; Milli Eğitim Bakanlığı'na bağlı ortaöğretim kurumları bünyesinde ve Yükseköğretim Kurumu'na bağlı üniversiteler bünyesinde verilmektedir (Sarığlan, 2012: 142). Yaygın eğitim ise; sertifikaya dayalı uzun ve kısa süreli kurslardan oluşmakta ve kamu ya da özel sektör bünyesindeki kurslar tarafından verilmektedir (Sarıŏlan, 2018: 269).

Türkiye'de ortaöğretim düzeyinde mutfak eğitimi ilk olarak 1962 yılında Ankara Otelcilik Okulu'nun açılmasıyla başlamıştır. Daha sonra ise ilk aşçılık lisesi olan Mengen Aşçllık Meslek Lisesi 1985 yılında eğitim vermeye başlamıştır. Milli Eğitim Bakanlığı tarafından 2002 yılında yapılan düzenleme ile Anadolu Turizm ve Otelcilik Liseleri bünyesinde mutfak eğitimi verilmeye başlanmıştır. 2005 yılından sonra ise gerekli şartları taşımaları ve yeterli donanıma sahip olmaları durumunda diğer meslek liselerine ve çok programlı liselere de mutfak eğitimi verme hakkı tanınmıştır (Kurnaz, Kurnaz ve Kılıç, 2014: 43-44). 2017 yılında yapılan son düzenleme ile meslek liseleri Mesleki ve Teknik Anadolu Liseleri adı altında toplanmış ve ortaöğretim düzeyinde mutfak eğitimi Mesleki ve Teknik Anadolu Liseleri ve Çok Programlı Anadolu Liseleri bünyesinde verilmeye başlanmıştır (Yılmaz, 2019: 233).

Türkiye' de yükseköğretim düzeyinde gastronomi eğitimi; önlisans, lisans ve lisansüstü düzeyde olmak üzere üç şekilde verilmektedir (Boyraz, Çetin, Mutlu ve Soybalı, 2018: 134; Çorbacı, Yılmaz ve Gültekin, 2018: 53). Önlisans düzeyinde gastronomi eğitimi meslek yüksekokulları bünyesinde aşçılık programı adıyla verilmektedir (Denk ve Koşan, 2017: 57). Önlisans düzeyinde eğitim ilk olarak 1997 yılında Bolu Abant İzzet Baysal Üniversitesi bünyesinde açılan aşçılık bölümüyle verilmeye başlanmıştır. Vakıf üniversiteleri bünyesinde ise ilk olarak Kapadokya Üniversitesi bünyesinde 2006 yılında verilmeye başlanmıştır (Görkem ve Sevim, 2016: 979; Bucak ve Yiğit, 2018: 811). Lisans düzeyinde gastronomi eğitimi; gastronomi, gastronomi ve mutfak sanatları, mutfak sanatları yönetimi ya da yiyecek içecek işletmeciliği program adlarıyla verilmektedir (Yılmaz, 2019: 236). Lisans düzeyinde gastronomi eğitimi ilk olarak 2003 yılında Yeditepe Üniversitesi Güzel Sanatlar Fakültesi bünyesinde gastronomi ve mutfak sanatları programında verilmeye başlanmıştır (Aksoy ve Şahin, 2018: 8; Aydemir ve Buyruk, 2019: 354). Devlet üniversiteleri bünyesinde ise ilk olarak Gazi Üniversitesi Turizm Fakültesi ve Nevşehir Hacı Bektaş Veli Üniversitesi Turizm Fakültesi'nde 2010 yılında verilmeye başlanmıştır (Görkem ve Sevim, 2011: 80; Özdemir vd., 2019: 948). Açıldığı günden itibaren öğrenciler tarafından talebin 
artmasıyla birlikte daha fazla programa ihtiyaç duyulduğu (Özbay, 2019: 25) ve bu yüzden her geçen yıl program sayısında artış yaşandığı ifade edilmektedir (Güdek ve Boylu, 2017: 491). Türkiye' de lisansüstü düzeyde gastronomi eğitiminin ise ilk olarak 2013 yılında Gazi Üniversitesi bünyesinde verilmeye başlandığı bilinmektedir (http://gazi-universitesi.gazi.edu.tr). Diğer ülkelere bakıldığında, lisansüstü düzeyde gastronomi eğitimi ilk olarak 1990'lı yıllarda Amerika ve Avusturalya gibi ülkelerde verilmeye başlanmıştır (Öney, 2016: 196; Yıldız ve Aslan, 2019: 1126). Bu doğrultuda Türkiye'deki gastronomi eğitiminde niceliksel ve niteliksel olarak geri kalındığını söylemek mümkündür (Sarığlan, 2014a: 261). Bu yüzden gastronomi eğitiminin geleceği için; gastronomi eğitimi alan öğrencilerin özellikle lisansüstü eğitime yönlendirilmesi ve alanında uzman akademik personelin yetiştirilmesi oldukça önem arz etmektedir (Şengül, 2019: 173).

Gastronomi eğitimine ilişkin literatür incelendiğinde; gastronominin turizm eğitimi ile ilişkisi (Santich, 2004; Hegarty, 2015), gastronomi ve mutfak sanatları eğitiminin tarihsel gelişiminin incelenmesi (Brown, 2005; Miles, 2007), gastronomi eğitiminde kurumsallaşma (Harrington, Mandabach, Thibodeaux ve Vanleewen, 2005), ülkeler arası gastronomi eğitim müfredatlarının karşılaştırılması (Hu, Chen ve Lin, 2006), gastronomi ve mutfak sanatları eğitiminde mükemmellik (Hegarty, 2011), mutfak eğitiminde maliyetlerin, istihdam sonuçlarının ve memnuniyetin değerlendirilmesi (Hertzman ve Mass, 2012), gastronomi eğitiminin mevcut durumunun değerlendirilmesi (Sarığlan, 2012; Lee ve Kim, 2013; Sarıŏlan, 2014a; Görkem ve Sevim, 2016; Öney, 2016; Ekincek vd., 2017; Çorbacı vd., 2018; Doğancılı, Karaçar ve Korkmaz, 2019; Sarışık ve Ceylan, 2019; Yılmaz, 2019), lisans düzeyinde gastronomi eğitiminin değerlendirilmesi (Aymankuy ve Demirbulat, 2017; Arslanhan ve Yaman, 2019; Beyter, Zıvalı ve Yalçın, 2019), yükseköğretim düzeyinde gastronomi eğitiminin değerlendirilmesi (Görkem ve Sevim, 2011), gastronomi eğitiminde yeni yönelimler (Brown, Mao ve Chesser, 2013; Sarıŏlan, 2014b), gastronomi ve mutfak sanatları programının diğer programlar ile karşılaştırılması (Aksoy ve Şahin, 2018), gastronomi eğitimindeki uygulamalı meslek derslerinin incelenmesi (Çarbuğa, Aydın, Sormaz ve Yılmaz, 2018), gastronomi eğitim kalitesinin değerlendirilmesi (Hertzman ve Stefanelli, 2007; Hertzman ve Ackerman, 2010; Zopiatis vd., 2014; Cankül, 2019; Yaman ve Bulduk, 2019), gastronomi eğitiminde profesyonel mutfak okullarının etkisi (Bucak ve Yiğit, 2018), gastronomi eğitiminde sosyal sorumluluk projesi örneği (Kurnaz vd., 2018), gastronomi ve mutfak sanatları programlarının gıda güvenliğine yönelik donanım düzeylerinin incelenmesi (Sevim ve Görkem, 2015), sürdürülebilir gastronomi eğitimi (Allievi vd., 2019), yaygın gastronomi eğitimi (Sarığlan, 2018), gastronomi eğitimi veren yükseköğretim kurumlarındaki eğitim mutfaklarında yaşanan sorunların incelenmesine (Arıkan, Sürücü ve Arman, 2018) yönelik ya da gastronomi eğitimi alan öğrencilere yönelik çalışmalar (Cha ve Park, 2005; Patah, Issa ve Nor, 2009; Edens, 2011; Choi ve Kim, 2014; Davras ve Davras, 2015; Akoğlu, Cansızoğlu, Orhan ve Özdemir, 2017; Deveci, Deveci ve Avcıkurt, 2017; Deveci, Deveci, Karaman ve Aymankuy, 2017; Güdek ve Boylu, 2017; Yazıcıoğlu ve Özata, 2017; Alyakut ve Küçükkömürler, 2018; Babaç ve Önçel, 2018; Boyraz vd., 2018; Deveci ve Deveci, 2018; Aydemir ve Buyruk, 2019; Can ve Çiftçi, 2019; Kurnaz, 2019; Özdemir vd., 2019; Yılmaz ve Çemrek, 2019) yapıldığ görülmektedir. Gastronomi eğitimi veren akademik personele ilişkin çalışmaların (Ekincek vd., 2017; Ülker ve Kılıçhan, 2017; Yazıcıŏlu ve Özata, 2018) ise oldukça kısıtlı olduğu görülmektedir.

Yapılan literatür taraması sonucunda gastronomi ve mutfak sanatları programında eğitim veren akademik personelin eğitim durumlarının incelendiği herhangi bir çalışmaya rastlanmamıştır. $\mathrm{Bu}$ doğrultuda yapılan bu çalışma ile gastronomi ve mutfak sanatları programı ve akademik personellere ilişkin mevcut bilgiler detaylı bir şekilde incelenmiş, geçmiş dönem ile kıyaslanmış ve geleceğe ilişkin öneriler sunulmuştur. Elde edilen sonuçlar ve sunulan öneriler ile çalışmanın ilgili literatüre katkı sağlayacağı düşünülmektedir. 


\section{YÖNTEM}

Araştırmanın temel amacl, Türkiye'deki devlet üniversitelerinin hangilerinde gastronomi ve mutfak sanatları lisans programı olduğu, kontenjan sayıları, lisansüstü program sayılarının ortaya konulması ayrıca gastronomi ve mutfak sanatları lisans bölümünde eğitim-öğretim faaliyetlerinde bulunan akademik personelin mevcut lisans ve lisansüstü eğitim durumlarının incelenmesi olarak belirlenmiştir. Araştırmanın sınırlılıklarını; sadece devlet üniversitelerinin incelenmesi, kavramsal çerçeve oluşturulurken sadece ulaşılabilen yerli-yabancı kaynakların kullanılması, elde edilen verilerin Mart 2020'den önceyi yansıtması ve araştırmada kullanılan betimsel nitelikli tarama yöntemi oluşturmaktadır.

Araştırmada veri toplama tekniği olarak nitel araştırma yöntemi olan betimsel nitelikli tarama modeli kullanılmıştır. Bunun temel sebebi, araştırmaya konu olan durum, olay, olgu, nesne ya da bireylerin kendi şartları içinde ve oldukları gibi betimlenmesine veya tanımlanmasına olanak sağlamasıdır. Ayrıca elde edilen sonuçların genellenebilir hale getirilmesine, sistematik bir tarama stratejisinin kullanılmasına ve seçilen olay, olgu, nesne veya bireylerin niteliklerinin kodlanmasına ve analiz edilmesine imkan tanımaktadır (Akarsu ve Akarsu, 2019; Aslan ve Uyar, 2019; Büyüköztürk, vd., 2016; Sönmez ve Alacapınar, 2016; Karasar, 2020; King ve He, 2005). Bu nedenle araştırmaya konu olan Türkiye'deki devlet üniversitelerinde bulunan gastronomi ve mutfak sanatları bölümleri ve akademik personel kendi şartları içerisinde oldukları gibi ve ulaşılabilen şekliyle tanımlanmaya çalışılmış ve raporlanmıştır.

Türkiye'deki gastronomi ve mutfak sanatları lisans programları ve bu programların yer aldığı üniversitelerin resmi internet sitelerinde bulunan bilgiler detaylı olarak incelenmiş̧ir. Araştırma devlet üniversiteleri ile sınırlandırılmış ve vakıf üniversiteleri araştırmaya dahil edilmemiştir. Yapılan inceleme doğrultusunda 37 üniversite bünyesindeki 40 kurumda lisans düzeyinde gastronomi ve mutfak sanatları eğitimi verildiği tespit edilmiştir. Bu kurumlara ilişkin bilgiler (fakülte/yüksekokul, kontenjan) Yükseköğretim Program Atlası aracılığıyla, kurumlarda istihdam edilen akademik personele ilişkin bilgiler (unvan, lisans, yüksek lisans ve doktora eğitim alanları) ise personel web sayfaları ve Yükseköğretim Akademik Arama Motoru aracılığıyla elde edilmiştir. Elde edilen bilgiler detaylı olarak incelenmiş ve rakamsal göstergeler halinde sunulmuştur.

\section{BULGULAR ve YORUMLAR}

Türkiye'de devlet üniversitelerinde lisans düzeyinde gastronomi ve mutfak sanatları eğitimi turizm fakülteleri, güzel sanatlar fakülteleri, uygulamalı bilimler fakülteleri, turizm işletmeciliği ve otelcilik yüksekokulları ya da uygulamalı bilimler yüksekokulları bünyesinde verilmektedir. Toplam 37 üniversite bünyesinde 28 Turizm Fakültesi, 2 Güzel Sanatlar Fakültesi, 1 Uygulamalı Bilimler Fakültesi, 5 Turizm İşletmeciliği ve Otelcilik Yüksekokulu, 4 Uygulamalı Bilimler Yüksekokulu'nda olmak üzere toplam 40 kurumda lisans düzeyinde gastronomi ve mutfak sanatları eğitimi verilmektedir. Programda 2188 kişi I. öğretim, 496 kişi II. öğretim olmak üzere toplam 2684 kontenjan bulunmaktadır (2019). 2019 Yükseköğretim Kurulu istatistiklerine göre bu kontenjanlara yerleşme oranı $\% 100$ 'dür. Lisans düzeyinde gastronomi ve mutfak sanatları eğitimi veren kurumların bilgileri Tablo 1'de detaylı olarak yer almaktadır.

Lisansüstü düzeyde gastronomi ve mutfak sanatları eğitimi veren kurumlar incelendiğinde; 15 üniversite bünyesinde yüksek lisans, 4 üniversite bünyesinde ise doktora programı bulunduğu görülmektedir. Mevcut bulunan lisansüstü programlar (+), bulunmayanlar ise (-) ile gösterilmektedir. Lisansüstü düzeyde gastronomi ve mutfak sanatları eğitimi veren kurumların bilgileri Tablo 2' de detaylı olarak yer almaktadır. 
Tablo 1. Türkiye'deki Devlet Üniversitelerinde Bulunan Gastronomi ve Mutfak Sanatları Lisans Programları (Mart, 2020)

\begin{tabular}{|c|c|c|c|}
\hline íl & Üniversite & Fakülte/Yüksekokul & Kontenjan \\
\hline Afyon & Afyon Kocatepe Üniversitesi & Turizm Fakültesi & $62+62$ \\
\hline Antalya & Akdeniz Üniversitesi & Manavgat Turizm Fakültesi & $103+93$ \\
\hline Antalya & Akdeniz Üniversitesi & Turizm Fakültesi & 72 \\
\hline Antalya & $\begin{array}{l}\text { Alanya Alaaddin Keykubat } \\
\text { Üniversitesi }\end{array}$ & Turizm Fakültesi & 62 \\
\hline Eskişehir & Anadolu Üniversitesi & Turizm Fakültesi & 62 \\
\hline Ankara & $\begin{array}{l}\text { Ankara Hacı Bayram Veli } \\
\text { Üniversitesi }\end{array}$ & Turizm Fakültesi & 60 \\
\hline Erzurum & Atatürk Üniversitesi & Turizm Fakültesi & $62+62$ \\
\hline Balıkesir & Balıkesir Üniversitesi & Turizm Fakültesi & 52 \\
\hline Bolu & $\begin{array}{l}\text { Bolu Abant İzzet Baysal } \\
\text { Üniversitesi }\end{array}$ & Turizm Fakültesi & 62 \\
\hline Burdur & $\begin{array}{l}\text { Burdur Mehmet Akif Ersoy } \\
\text { Üniversitesi }\end{array}$ & $\begin{array}{l}\text { Turizm İşletmeciliği ve } \\
\text { Otelcilik Yüksekokulu }\end{array}$ & $62+62$ \\
\hline Çanakkale & $\begin{array}{l}\text { Çanakkale Onsekiz Mart } \\
\text { Üniversitesi }\end{array}$ & Turizm Fakültesi & 41 \\
\hline Çanakkale & $\begin{array}{l}\text { Çanakkale Onsekiz Mart } \\
\text { Üniversitesi }\end{array}$ & $\begin{array}{l}\text { Gökçeada Uygulamalı } \\
\text { Bilimler Yüksekokulu }\end{array}$ & 52 \\
\hline İzmir & Dokuz Eylül Üniversitesi & $\begin{array}{l}\text { Reha Midilli Foça Turizm } \\
\text { Fakültesi }\end{array}$ & 52 \\
\hline İzmir & Dokuz Eylül Üniversitesi & $\begin{array}{l}\text { Seferihisar Fevziye Hepkon } \\
\text { Uygulamalı Bilimler } \\
\text { Yüksekokulu }\end{array}$ & 62 \\
\hline Eskişehir & $\begin{array}{l}\text { Eskişehir Osmangazi } \\
\text { Üniversitesi }\end{array}$ & Turizm Fakültesi & 41 \\
\hline Gaziantep & Gaziantep Üniversitesi & Güzel Sanatlar Fakültesi & 62 \\
\hline Iğdır & Iğdır Üniversitesi & Turizm Fakültesi & 41 \\
\hline Hatay & İskenderun Teknik Üniversitesi & Turizm Fakültesi & 41 \\
\hline İstanbul & $\begin{array}{l}\text { İstanbul Medeniyet } \\
\text { Üniversitesi }\end{array}$ & Turizm Fakültesi & 52 \\
\hline İzmir & İzmir Katip Çelebi Üniversitesi & Turizm Fakültesi & 62 \\
\hline Karabük & Karabük Üniversitesi & Safranbolu Turizm Fakültesi & 52 \\
\hline Karaman & $\begin{array}{l}\text { Karamanoğlu Mehmet Bey } \\
\text { Üniversitesi }\end{array}$ & $\begin{array}{l}\text { Uygulamalı Bilimler } \\
\text { Yüksekokulu }\end{array}$ & 26 \\
\hline Kastamonu & Kastamonu Üniversitesi & Turizm Fakültesi & 52 \\
\hline Kırklareli & Kırklareli Üniversitesi & Turizm Fakültesi & 41 \\
\hline Kocaeli & Kocaeli Üniversitesi & $\begin{array}{l}\text { Turizm İşletmeciliği ve } \\
\text { Otelcilik Yüksekokulu }\end{array}$ & 62 \\
\hline Kütahya & $\begin{array}{l}\text { Kütahya Dumlupınar } \\
\text { Üniversitesi }\end{array}$ & $\begin{array}{l}\text { Tavşanlı Uygulamalı Bilimler } \\
\text { Fakültesi }\end{array}$ & 31 \\
\hline Mardin & Mardin Artuklu Üniversitesi & Turizm Fakültesi & $62+31$ \\
\hline Mersin & Mersin Üniversitesi & Turizm Fakültesi & 62 \\
\hline Tunceli & Munzur Üniversitesi & Güzel Sanatlar Fakültesi & 52 \\
\hline
\end{tabular}




\begin{tabular}{|l|l|l|c|}
\hline Konya & $\begin{array}{l}\text { Necmettin Erbakan } \\
\text { Üniversitesi }\end{array}$ & Turizm Fakültesi & $62+62$ \\
\hline Nevşehir & $\begin{array}{l}\text { Nevşehir Hacı Bektaş Veli } \\
\text { Üniversitesi }\end{array}$ & Turizm Fakültesi & $62+62$ \\
\hline Osmaniye & $\begin{array}{l}\text { Osmaniye Korkut Ata } \\
\text { Üniversitesi }\end{array}$ & $\begin{array}{l}\text { Kadirli Uygulamalı Bilimler } \\
\text { Yüksekokulu }\end{array}$ & 52 \\
\hline Denizli & Pamukkale Üniversitesi & Turizm Fakültesi & 72 \\
\hline Rize & $\begin{array}{l}\text { Recep Tayyip Erdoğan } \\
\text { Üniversitesi }\end{array}$ & Ardeşen Turizm Fakültesi & 41 \\
\hline Sakarya & $\begin{array}{l}\text { Sakarya Uygulamalı Bilimler } \\
\text { Üniversitesi }\end{array}$ & Turizm Fakültesi & 52 \\
\hline Konya & Selçuk Üniversitesi & Turizm Fakültesi & $62+62$ \\
\hline Sinop & Sinop Üniversitesi & $\begin{array}{l}\text { Turizm İşletmeciliği ve } \\
\text { Otelcilik Yüksekokulu }\end{array}$ & 41 \\
\hline Sivas & Sivas Cumhuriyet Üniversitesi & Turizm Fakültesi & 62 \\
\hline Şırnak & Şırnak Üniversitesi & $\begin{array}{l}\text { Turizm İşletmeciliği ve } \\
\text { Otelcilik Yüksekokulu }\end{array}$ & 41 \\
\hline Tokat & $\begin{array}{l}\text { Tokat Gaziosmanpaşa } \\
\ddot{n} \text { Ziversitesi }\end{array}$ & $\begin{array}{l}\text { Zile Dinçerler Turizm } \\
\text { İsletmeciliği ve Otelcilik } \\
\text { Yüksekokulu }\end{array}$ & 36 \\
\hline
\end{tabular}

Kaynak: https://yokatlas.yok.gov.tr/ ve https://www.yok.gov.tr/universiteler/universitelerimiz sitelerinden yazarlar tarafından derlenerek hazırlanmıştır.

Tablo 2. Türkiye'deki Devlet Üniversitelerinde Bulunan Gastronomi ve Mutfak Sanatları Lisansüstü Programları (Mart, 2020)

\begin{tabular}{|l|c|c|}
\hline \multicolumn{1}{|c|}{ Üniversite } & Yüksek Lisans & Doktora \\
\hline Akdeniz Üniversitesi & + & + \\
\hline Ankara Hacı Bayram Veli Üniversitesi & + & + \\
\hline Balıkesir Üniversitesi & + & + \\
\hline Bolu Abant İzzet Baysal Üniversitesi & + & - \\
\hline Dokuz Eylül Üniversitesi & + & - \\
\hline Eskişehir Osmangazi Üniversitesi & + & - \\
\hline Gaziantep Üniversitesi & + & - \\
\hline Karabük Üniversitesi & + & - \\
\hline Mardin Artuklu Üniversitesi & + & - \\
\hline Mersin Üniversitesi & + & + \\
\hline Necmettin Erbakan Üniversitesi & + & - \\
\hline Nevşehir Hacı Bektaş Veli Üniversitesi & + & - \\
\hline Pamukkale Üniversitesi & + & - \\
\hline Sakarya Uygulamalı Bilimler Üniversitesi & + & + \\
\hline Karamanoğlu Mehmet Bey Üniversitesi & + & - \\
\hline
\end{tabular}

Kaynak: Üniversitelerin resmi web sitelerinden yazarlar tarafından derlenerek hazırlanmıştır.

Lisans düzeyinde gastronomi ve mutfak sanatları eğitimi veren 40 kurumda toplam 243 akademik personel bulunmaktadır. Bu akademisyenlerin 18'i profesör, 37'si doçent, 98'i doktor öğretim üyesi, 5'i araştırma görevlisi doktor, 59'u araştırma görevlisi, 1'i öğretim görevlisi doktor, 25 'i ise öğretim görevlisidir. Sayı bazında incelendiğinde doktor öğretim üyesi unvanına sahip olan akademik personelin çoğunlukta olduğu görülmektedir. Doktor öğretim üyesinden sonra 
ise araştırma görevlisi unvanına sahip olan akademik personelin çoğunlukta olduğu görülmektedir. Akademik personelin unvanları ve hangi kurumlara bağlı olarak çalıştığına ilişkin bilgiler Tablo 3'te detaylı olarak yer almaktadır.

Tablo 3. Türkiye'deki Devlet Üniversitelerinde Bulunan Gastronomi ve Mutfak Sanatları Programlarının Akademik Personel Sayıları (Mart, 2020)

\begin{tabular}{|c|c|c|c|c|c|c|c|}
\hline Üniversite & $\begin{array}{l}\dot{\Delta} \\
\dot{\Delta} \\
\dot{0}\end{array}$ & $\begin{array}{l}\dot{\dot{H}} \\
\dot{\circ} \\
\dot{D}\end{array}$ & مَ: & 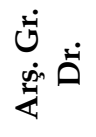 & $\begin{array}{l}\dot{U} \\
\dot{\dot{x}}\end{array}$ & ن் & ن் \\
\hline Afyon Kocatepe Üniversitesi & - & 2 & 1 & - & 1 & - & 2 \\
\hline Akdeniz Üniversitesi & 2 & 2 & 4 & - & 3 & - & - \\
\hline Alanya Alaaddin Keykubat Üniversitesi & - & 2 & 2 & - & - & - & - \\
\hline Anadolu Üniversitesi & - & 2 & 3 & 1 & 3 & - & - \\
\hline Ankara Hacı Bayram Veli Üniversitesi & 3 & 3 & 5 & 1 & - & - & - \\
\hline Atatürk Üniversitesi & - & 1 & 4 & - & 2 & - & - \\
\hline Balıkesir Üniversitesi & 2 & 3 & - & 1 & 3 & - & - \\
\hline Bolu Abant İzzet Baysal Üniversitesi & - & - & 3 & - & 1 & - & 2 \\
\hline Burdur Mehmet Akif Ersoy Üniversitesi & - & - & 3 & - & 2 & - & 2 \\
\hline Çanakkale Onsekiz Mart Üniversitesi & 1 & - & 4 & - & 2 & - & 2 \\
\hline Dokuz Eylül Üniversitesi & 1 & 2 & 3 & 1 & 1 & - & - \\
\hline Eskişehir Osmangazi Üniversitesi & 1 & 2 & 1 & - & 1 & 1 & 1 \\
\hline Gaziantep Üniversitesi & - & - & 6 & - & 2 & - & 1 \\
\hline Iğdır Üniversitesi & - & - & 3 & - & - & - & - \\
\hline İskenderun Teknik Üniversitesi & - & 1 & 2 & - & - & - & - \\
\hline İstanbul Medeniyet Üniversitesi & - & - & 2 & - & 1 & - & 2 \\
\hline İzmir Katip Çelebi Üniversitesi & 1 & 2 & 1 & - & 3 & - & 1 \\
\hline Karabük Üniversitesi & - & 2 & 1 & - & 4 & - & - \\
\hline Karamanoğlu Mehmet Bey Üniversitesi & 1 & - & 2 & - & - & - & - \\
\hline Kastamonu Üniversitesi & - & - & 4 & - & 3 & - & - \\
\hline Kırklareli Üniversitesi & - & - & 3 & - & 1 & - & - \\
\hline Kocaeli Üniversitesi & - & 1 & 2 & - & - & - & - \\
\hline Kütahya Dumlupınar Üniversitesi & - & - & 3 & - & - & - & 1 \\
\hline Mardin Artuklu Üniversitesi & - & 1 & 3 & - & 2 & - & - \\
\hline Mersin Üniversitesi & - & 1 & 4 & - & 2 & - & 3 \\
\hline Munzur Üniversitesi & - & 2 & 2 & - & 5 & - & 1 \\
\hline Necmettin Erbakan Üniversitesi & 1 & 1 & 4 & - & 2 & - & - \\
\hline Nevşehir Hacı Bektaş Veli Üniversitesi & - & 3 & 2 & - & 1 & - & 2 \\
\hline Osmaniye Korkut Ata Üniversitesi & - & - & 3 & - & 3 & - & - \\
\hline Pamukkale Üniversitesi & 1 & - & 2 & 1 & 2 & - & - \\
\hline Recep Tayyip Erdoğan Üniversitesi & - & - & 3 & - & 1 & - & - \\
\hline Sakarya Uygulamalı Bilimler Üniversitesi & 2 & 2 & 1 & - & 4 & - & - \\
\hline Selçuk Üniversitesi & 2 & - & 3 & - & - & - & 1 \\
\hline Sinop Üniversitesi & - & - & 2 & - & - & - & - \\
\hline Sivas Cumhuriyet Üniversitesi & - & 1 & 2 & - & 1 & - & 3 \\
\hline Şırnak Üniversitesi & - & - & 3 & - & 2 & - & 1 \\
\hline Tokat Gaziosmanpaşa Üniversitesi & - & 1 & 2 & - & 1 & - & - \\
\hline Toplam & 18 & 37 & 98 & 5 & 59 & 1 & 25 \\
\hline
\end{tabular}

Kaynak: Üniversitelerin resmi web siteleri ve https://akademik.yok.gov.tr/AkademikArama/ sitesinden yazarlar tarafından derlenerek hazırlanmıştır. 
Lisans düzeyinde gastronomi ve mutfak sanatları eğitimi veren kurumlarda istihdam edilen akademik personelin eğitim durumları ve mezuniyet alanları detaylı bir şekilde incelenmiş ve bunlara ilişkin bilgiler Tablo 4, Tablo 5 ve Tablo 6' da sunulmuştur. Lisans mezuniyeti açısından 18 profesörden $9^{\prime} \mathrm{u}, 37$ doçentten $24^{\prime}$ ü, 98 doktor öğretim üyesinden $45^{\prime}$ i, 5 araştırma görevlisi doktordan 4'ü, 59 araştırma görevlisinden 46'sı, 25 öğretim görevlisinden 13'ü turizm alanlarından mezundur. Toplam akademik personel içerisinde bulunan 1 öğretim görevlisi doktor da turizm alanı mezunudur. Gastronomi ve mutfak sanatları programinda istihdam edilen akademik personelin lisans mezuniyet alanları Tablo 4 'te detaylı olarak yer almaktadır. (1 doktor öğretim üyesi, 3 araştırma görevlisi, 1 öğretim görevlisinin lisans mezuniyetlerine ilişkin bilgilere ulaşılamamıştır. Bu nedenle ulaşılamayan veriler toplam akademik personel sayılarından eksiltilerek Tablo 4'te gösterilmiştir.)

Tablo 4. Akademik Personelin Lisans Mezuniyet Alanları (Mart, 2020)

\begin{tabular}{|c|c|c|c|c|c|c|c|}
\hline Bölüm & $\begin{array}{l}\dot{\vec{D}} \\
\dot{\mathrm{g}}\end{array}$ & $\begin{array}{l}\dot{\vec{\Delta}} \\
\dot{\circ}\end{array}$ & خأ : & 它 & 它 & نُ & ס் \\
\hline Aile ekonomisi ve beslenme eğitimi & - & 3 & 3 & - & - & - & - \\
\hline $\begin{array}{l}\text { Aile ekonomisi ve beslenme eğit. } \\
\text { öğretmenliği }\end{array}$ & - & - & 1 & - & - & - & - \\
\hline Aile ve tüketici bilimleri eğitimi & - & 1 & - & - & - & - & - \\
\hline Alman dili ve edebiyatı & - & - & - & - & - & - & 1 \\
\hline Almanca öğretmenliği & - & - & 1 & - & - & - & - \\
\hline Balıkçlık teknolojisi mühendisliği & - & - & 1 & - & - & - & - \\
\hline Beslenme ve diyetetik & - & - & 1 & - & - & - & - \\
\hline Bilgisayar öğretmenliği & 1 & - & - & - & - & - & - \\
\hline Biyoloji & - & 1 & 2 & - & - & - & - \\
\hline Çalışma ekonomisi ve endüstri ilişkileri & - & 1 & - & - & - & - & - \\
\hline Çevre mühendisliği & - & - & - & 1 & - & - & - \\
\hline Çocuk gelişimi ve ev yönetimi eğitimi & - & - & 1 & - & - & - & - \\
\hline Endüstri mühendisliği & - & - & - & - & 1 & - & - \\
\hline Ev idaresi ve aile ekonomisi & - & - & - & - & - & - & 1 \\
\hline Ev ekonomisi & 1 & - & - & - & - & - & - \\
\hline Fransız dili eğitimi & - & - & - & - & - & - & 1 \\
\hline Gastronomi ve mutfak sanatları & - & - & - & - & 22 & - & 3 \\
\hline Gida bilimi ve teknolojisi & 1 & - & - & - & - & - & - \\
\hline Gida hijyeni ve teknolojisi & - & - & 1 & - & - & - & - \\
\hline Glda mühendisliği & - & 4 & 27 & - & 4 & - & 3 \\
\hline Hayvansal üretim & - & - & 1 & - & - & - & - \\
\hline İktisat & 1 & - & - & - & - & - & - \\
\hline İşletme & 1 & 1 & 5 & - & 1 & - & 3 \\
\hline Kimya & - & - & - & - & 1 & - & - \\
\hline Kimya mühendisliği & - & - & - & - & 2 & - & - \\
\hline Konaklama işletmeciliği & - & 5 & 11 & 1 & 2 & - & 1 \\
\hline Konaklama işletmeciliği öğretmenliği & - & 1 & 2 & - & - & - & - \\
\hline Mutfak sanatları yönetimi & - & - & - & - & 3 & - & - \\
\hline $\begin{array}{l}\text { Ortaöğretim fen ve matematik alanlar } \\
\text { eğitimi }\end{array}$ & - & 1 & - & - & - & - & - \\
\hline
\end{tabular}




\begin{tabular}{|l|c|c|c|c|c|c|c|}
\hline Peyzaj mimarlı̆̆ & 1 & - & - & - & - & - & - \\
\hline Seyahat işletmeciliği & - & 1 & 1 & - & 1 & - & - \\
\hline Siyaset bilimi ve kamu yönetimi & - & - & 1 & - & - & - & - \\
\hline Su ürünleri & - & - & 2 & - & - & - & - \\
\hline Su ürünleri mühendisliği & - & - & 1 & - & - & - & - \\
\hline Süt teknolojisi & 1 & 1 & 1 & - & - & - & - \\
\hline Tarla bitkileri & - & - & 1 & - & - & - & - \\
\hline Ticaret eğitimi & 1 & - & - & - & - & - & - \\
\hline Turizm işletmeciliği & - & 1 & 6 & - & 4 & - & 1 \\
\hline Turizm işletmeciliği eğitimi & - & 3 & 6 & 2 & - & 1 & 2 \\
\hline Turizm işletmeciliği ve otelcilik & 9 & 9 & 12 & - & 1 & - & 2 \\
\hline Turizm işletmeciliği ve otelcilik & - & 1 & 1 & - & - & - & - \\
öğretmenliği & & & & & & & \\
\hline Turizm ve otel işletmeciliği & - & 2 & 3 & 1 & 2 & - & 1 \\
\hline Turist rehberliği & - & 1 & 1 & - & 1 & - & - \\
\hline Turizm rehberliği & - & - & 2 & - & 3 & - & - \\
\hline Türkçe öğretmenliği & - & - & - & - & 1 & - & - \\
\hline Veteriner hekimliği & 1 & - & - & - & - & - & 1 \\
\hline Yabancı diller eğitimi & - & - & 2 & - & - & - & 1 \\
\hline Yiyecek ve içecek işletmeciliği & - & - & - & - & 7 & - & 3 \\
\hline Toplam & $\mathbf{1 8}$ & $\mathbf{3 7}$ & $\mathbf{9 7}$ & $\mathbf{5}$ & $\mathbf{5 6}$ & $\mathbf{1}$ & $\mathbf{2 4}$ \\
\hline
\end{tabular}

Kaynak: Üniversitelerin resmi web siteleri ve https://akademik.yok.gov.tr/AkademikArama/ sitesinden yazarlar tarafından derlenerek hazırlanmıştır.

Yüksek lisans mezuniyeti açısından 18 profesörden $9^{\prime} \mathbf{u}, 37$ doçentten 19'u, 98 doktor öğretim üyesinden 42'si, 5 araştırma görevlisi doktordan 4'ü turizm alanlarından mezundur. Toplam akademik personel içerisinde bulunan 1 öğretim görevlisi doktor da turizm alanı mezunudur. 59 araştırma görevlisinden 47 'sinin ve 25 öğretim görevlisinden 13'ünün yüksek lisans mezuniyeti/devam eden eğitimi turizm alanındadır. Yüksek lisans mezuniyeti açısından turizm alanlarından sonra gıda mühendisliği programından mezun olan akademik personelin sayısının fazla olduğu görülmektedir. Gastronomi ve mutfak sanatları programında istihdam edilen akademik personelin yüksek lisans mezuniyetleri Tablo 5 'te detaylı olarak yer almaktadır. (1 doktor öğretim üyesinin yüksek lisans mezuniyetine ilişkin bilgi bulunmamaktadır. Aynı zamanda 4 araştırma görevlisi ve 8 öğretim görevlisinin yüksek lisans mezuniyeti ya da eğitime devam ettiğine ilişkin bilgilere ulaşılamamıştır. Bu nedenle ulaşılamayan veriler toplam akademik personel sayılarından eksiltilerek Tablo 5'te gösterilmişstir).

Doktora mezuniyeti açısından 18 profesörden $8^{\prime} i$, 37 doçentten $18^{\prime} i$, 98 doktor öğretim üyesinden 45'i, 5 araştırma görevlisi doktordan 5'i turizm alanlarından mezundur. Toplam akademik personel içerisinde bulunan 1 öğretim görevlisi doktor da turizm alanı mezunudur. 59 araştırma görevlisinden 28 'inin ve 25 öğretim görevlisinden 6 'sının devam eden eğitimi turizm alanındadır. Gastronomi ve mutfak sanatları programinda istihdam edilen akademik personelin doktora mezuniyetleri Tablo 6'da detaylı olarak yer almaktadır. (1 doktor öğretim üyesinin doktora mezuniyetine ilişkin bilgi bulunmamaktadır. Ayn zamanda 25 araştırma görevlisi ve 16 öğretim görevlisinin doktora mezuniyeti ya da eğitime devam ettiğine ilişkin bilgi bulunmamaktadır. Bu nedenle ulaşılamayan veriler toplam akademik personel sayılarından eksiltilerek Tablo 6'da gösterilmiştir). 
Tablo 5. Akademik Personelin Yüksek Lisans Mezuniyet/Devam Eden Eğitim Alanları (Mart, 2020)

\begin{tabular}{|c|c|c|c|c|c|c|c|}
\hline Bölüm & $\begin{array}{l}\dot{\vec{D}} \\
\text { प्रें }\end{array}$ & $\begin{array}{l}\dot{\vec{H}} \\
\dot{\Delta} \\
\dot{\circ}\end{array}$ & مُ & 它 & 它 & $\begin{array}{l}\dot{U} \\
0 \\
0\end{array}$ & $\begin{array}{l}\dot{0} \\
: 00 \\
: 0\end{array}$ \\
\hline Aile ekonomisi ve beslenme eğitimi & - & 1 & 3 & - & - & - & - \\
\hline Besin hijyeni ve teknolojisi & - & & 2 & - & - & - & - \\
\hline Beslenme ve diyetetik & - & 1 & 1 & - & - & - & - \\
\hline Beslenme ve gida bilimleri & - & - & 1 & - & - & - & - \\
\hline Biyoloji & - & - & 3 & - & - & - & - \\
\hline Eğitim yönetimi teftişi planlaması ve ev eko & - & - & - & - & - & - & 1 \\
\hline Ev ekonomisi & 1 & - & - & - & - & - & - \\
\hline Ev ekonomisi ve beslenme & - & 2 & 1 & - & - & - & - \\
\hline Farmakoloji ve toksiloji & 1 & - & - & - & - & - & - \\
\hline Fen ve matematik alanlar eğitimi & - & 1 & - & - & - & - & - \\
\hline Gastronomi ve mutfak sanatları & - & - & - & - & 30 & - & 5 \\
\hline Gida bilimi ve teknolojisi & 1 & - & - & - & - & - & - \\
\hline Gida hijyeni ve teknolojisi & - & - & 1 & - & - & - & - \\
\hline Gıda mühendisliği & 1 & 4 & 27 & - & 4 & - & 3 \\
\hline Gida teknolojisi & - & 1 & - & - & - & - & - \\
\hline Halkla ilişkiler ve reklamcılık & - & 1 & - & - & - & - & - \\
\hline Halkla ilişkiler ve tanıtım & 1 & - & 1 & - & - & - & - \\
\hline İngiliz dili ve edebiyatı & - & - & 1 & - & - & - & - \\
\hline İktisat & - & 1 & 1 & - & - & - & - \\
\hline İktisat politikası & 1 & - & - & - & - & - & - \\
\hline İşletme & 2 & 4 & 6 & - & - & - & - \\
\hline İşletme mühendisliği & - & - & - & - & 1 & - & - \\
\hline Kalite yönetimi & - & - & - & 1 & - & - & - \\
\hline Kamu yönetimi & - & - & 1 & - & - & - & - \\
\hline Kimya mühendisliği & - & - & - & - & 2 & - & - \\
\hline Maliye & - & 1 & - & - & - & - & - \\
\hline Otel işletmeciliği & 1 & - & - & - & - & - & - \\
\hline Otel ve gıda servisi işletmeciliği & 1 & - & - & - & - & - & - \\
\hline Peyzaj mimarlığ1 & 1 & - & - & - & - & - & - \\
\hline Sağlık kuruluşları yöneticiliği & - & - & 1 & - & - & - & - \\
\hline Su ürünleri avlama ve işleme teknolojisi & - & - & 1 & - & - & - & - \\
\hline Su ürünleri mühendisliği & - & - & 2 & - & - & - & - \\
\hline Tarla bitkileri & - & - & 1 & - & - & - & - \\
\hline Temel tıp bilimleri & - & 1 & - & - & - & - & - \\
\hline Turizm işletmeciliği & 2 & 10 & 24 & 3 & 12 & - & 7 \\
\hline Turizm işletmeciliği eğitimi & 1 & 3 & 6 & 1 & - & 1 & - \\
\hline Turizm işletmeciliği ve otelcilik & 4 & 4 & 11 & - & 5 & - & 1 \\
\hline Turizm ve otel işletmeciliği & - & 2 & 1 & - & - & - & - \\
\hline Türkçe eğitimi & - & - & - & - & 1 & - & - \\
\hline Üretim yönetimi ve endüstri işletmeciliği & - & - & 1 & - & - & - & - \\
\hline Toplam & 18 & 37 & 97 & 5 & 55 & 1 & 17 \\
\hline
\end{tabular}

Kaynak: Üniversitelerin resmi web siteleri ve https://akademik.yok.gov.tr/AkademikArama/ sitesinden derlenerek yazarlar tarafından hazırlanmıştır. 
Tablo 6. Akademik Personelin Doktora Mezuniyet/Devam Eden Eğitim Alanları (Mart, 2020)

\begin{tabular}{|c|c|c|c|c|c|c|c|}
\hline Bölüm & 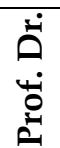 & $\begin{array}{l}\dot{\vec{D}} \\
\dot{\leftrightarrow}\end{array}$ & فأ் & $\underset{\dot{u}}{\dot{m}}$ & 守 & نُ & ن் \\
\hline Aile ekonomisi ve beslenme eğitimi & - & 3 & 5 & - & - & - & - \\
\hline Besin hijyeni ve teknolojisi & - & - & 1 & - & - & - & - \\
\hline Beslenme & - & - & 1 & - & - & - & - \\
\hline Beslenme ve diyetetik & - & 1 & 1 & - & - & - & - \\
\hline Biyoloji & - & - & 2 & - & - & - & - \\
\hline Biyomühendislik & - & - & - & - & 1 & - & - \\
\hline Eğitimde ölçme ve değerlendirme & 1 & - & - & - & - & - & - \\
\hline Enerji & - & - & 1 & - & - & - & - \\
\hline Ev ekonomisi & 1 & - & - & - & - & - & - \\
\hline Ev yönetimi ve beslenme eğitimi & - & - & 1 & - & - & - & - \\
\hline Farmakoloji ve toksiloji & 1 & - & - & - & - & - & - \\
\hline Gastronomi ve mutfak sanatları & - & - & 1 & - & 15 & - & 4 \\
\hline Gida bilimi ve beslenme & - & - & 1 & - & - & - & - \\
\hline Gida hijyeni ve teknolojisi & - & - & 1 & - & - & - & - \\
\hline Gıda mühendisliği & 1 & 4 & 25 & - & 1 & - & 3 \\
\hline Gida teknolojisi & - & 1 & - & - & - & - & - \\
\hline Halka ilişkiler ve reklamcılık & - & 1 & - & - & - & - & - \\
\hline Halkla ilişkiler ve tanıtım & 1 & 1 & 1 & - & - & - & - \\
\hline İktisat & 1 & 1 & - & - & - & - & - \\
\hline İngiliz dili ve edebiyatı & - & - & 1 & - & - & - & - \\
\hline İşletme & 2 & 5 & 4 & - & - & - & - \\
\hline İşletme mühendisliği & - & - & - & - & 1 & - & - \\
\hline Kimya & - & 1 & - & - & & - & - \\
\hline Kimya mühendisliği & - & - & - & - & 2 & - & - \\
\hline Muhasebe & - & - & 1 & - & - & - & - \\
\hline Peyzaj mimarlığ & 1 & - & - & - & - & - & - \\
\hline Rekreasyon yönetimi & - & - & 1 & - & - & 1 & - \\
\hline Su ürünleri avlama ve işleme teknolojisi & - & - & 1 & - & - & - & - \\
\hline Su ürünleri mühendisliği & - & - & 2 & - & - & - & - \\
\hline Tarım ekonomisi & 1 & - & - & - & - & - & - \\
\hline Tarla bitkileri & - & - & 1 & - & - & - & - \\
\hline Temel tıp bilimleri & - & 1 & - & - & - & - & - \\
\hline Turizm işletmeciliği & 5 & 11 & 34 & 4 & 10 & - & 2 \\
\hline Turizm işletmeciliği eğitimi & 1 & 3 & 2 & - & - & - & - \\
\hline Turizm işletmeciliği ve otelcilik & 2 & 4 & 7 & 1 & 3 & - & - \\
\hline Türkçe eğitimi & - & - & - & - & 1 & - & - \\
\hline Üretim yönetimi ve pazarlama & - & - & 1 & - & - & - & - \\
\hline Zootekni & - & - & 1 & - & - & - & - \\
\hline Toplam & 18 & 37 & 97 & 5 & 34 & 1 & 9 \\
\hline
\end{tabular}

Kaynak: Üniversitelerin resmi web siteleri ve https:/akademik.yok.gov.tr/AkademikArama/ sitesinden yazarlar tarafından derlenerek hazırlanmıştır. 


\section{SONUÇ ve ÖNERILLER}

Yapılan bu çalışmada Türkiye'deki devlet üniversitelerinde lisans ve lisansüstü düzeyde gastronomi ve mutfak sanatları eğitimi hakkında bilgi verilmiş ve bu programlarda görev yapan akademik personelin unvanları ve eğitim alanları incelenmiştir. Yapılan incelemeler neticesinde elde edilen bulgular rakamsal göstergeler şeklinde detaylı olarak sunulmuştur. Devlet üniversitelerindeki lisans düzeyinde gastronomi ve mutfak sanatları programına ilişkin Yükseköğretim Kurulu'nun geçmiş yıllarına ait verilerine bakıldığında; 2016 yılında 916, 2017 yılında 1496, 2018 yılında 1932, 2019 yılında ise 2684 kişilik kontenjan olduğu görülmektedir. 2016 yılından günümüze kadar geçen süreçte kontenjan sayısının arttığı ve yerleşme oranının $\% 100$ 'e kadar ulaştığı gözlemlenmektedir. Dört yıl içerisinde gerçekleşen artışın önümüzdeki süreçte de devam edeceği düşünülmektedir. Öngörülen durumun gerçekleşmesi halinde, gastronomi ve mutfak sanatları programından mezun olan öğrencilerin sayısında artış görülmesi kaçınılmaz olacaktır. Bu durumun mezun öğrenci enflasyonuna sebep olacağı ve istihdam açısından sorunların ortaya çıkacağı varsayılmaktadır.

Devlet üniversitelerindeki lisansüstü düzeyde gastronomi ve mutfak sanatları programına ilişkin 2017 verilerine bakıldığında 11 üniversitede yüksek lisans, 1 üniversitede ise doktora programı bulunduğu görülmektedir (Aymankuy ve Demirbulat, 2017: 235). 2020 yılı itibariyle 15 üniversitede yüksek lisans, 4 üniversitede ise doktora programı bulunmaktadır. Üç yıl içerisinde olan artışın önümüzdeki süreçte de devam edeceği öngörülmektedir. Bu programlar sayesinde alanında uzman kişilerin sayılarında artış sağlanabilir ve bu durum gastronomi ve mutfak sanatları programında istihdam edilecek akademik personel niteliğine katkı sağlayabilir. Gastronomi ve mutfak sanatları lisans programına sahip 37 devlet üniversitesinin, \%40,54'ünde gastronomi ve mutfak sanatları yüksek lisans programı ve \%10.81'inde gastronomi ve mutfak sanatları doktora programı bulunmaktadır.

Devlet üniversiteleri bünyesindeki gastronomi ve mutfak sanatları programında görev yapan toplam 243 akademik personel bulunmaktadır. Bu akademik personelin \%7,4'ü profesör, $\% 15,23$ 'ü doçent, \%40,34'ü doktor öğretim üyesi, \%2,05'i araştırma görevlisi doktor, \%24,29'u araştırma görevlisi, \%0,41'i öğretim görevlisi doktor ve \%10,28'i öğretim görevlisi olarak görev yapmaktadır.

Eğitim alanları incelendiğinde bu 243 akademik personelin 142'sinin lisans mezuniyeti, 135'inin yüksek lisans mezuniyeti/devam eden eğitimi ve 111'inin doktora mezuniyeti/devam eden eğitimi turizm alanındadır. Toplam akademik personelin \%58,43'ünün turizm lisans derecesine sahip olduğu, \%55,55'inin turizm yüksek lisans derecesine sahip olduğu/eğitimine devam ettiği ve $\% 45,67$ 'sinin turizm doktora derecesine sahip olduğu/eğitimine devam ettiği belirlenmiştir. Araştırmaya dahil olan 243 akademik personelin 96'sının hem lisans hem yüksek lisans hem de doktora eğitimi turizm alanındadır. Bu sayı toplam akademik personelin \%39,50'sini oluşturmaktadır.

Turizm lisans derecesine sahip olan 142 akademik personelin \%6,35'i profesör, \%16,90'ı doçent, \%31,71'i doktor öğretim üyesi, \%2,81'i araştırma görevlisi doktor, \%32,39'u araştırma görevlisi, $\% 0,70$ 'i öğretim görevlisi doktor ve \%9,15'inin öğretim görevlisi olduğu saptanmıştır. Turizm yüksek lisans derecesine sahip olan/eğitimi devam eden 135 akademik personelin \%6,66's1 profesör, \%14,07'si doçent, \%31,14'ü doktor öğretim üyesi, \%2,96'sı araştırma görevlisi doktor, $\% 34,81$ 'i araştırma görevlisi, \%0,74'ü öğretim görevlisi doktor ve \%9,62'sinin öğretim görevlisi olduğu belirlenmiştir. Turizm doktora derecesine sahip olan/eğitimi devam eden 111 akademik personelin \%7,20'si profesör, \%16,22'si doçent, \%40,55'i doktor öğretim üyesi, \%4,50'si araştırma görevlisi doktor, \%25,23'ü araştırma görevlisi, \%0,90'1 öğretim görevlisi doktor ve \%5,40'ının öğretim görevlisi olduğu tespit edilmiştir. Lisans, yüksek lisans ve doktora derecelerinin tamamı 
turizm alanında olan 96 akademik personelin \%7,29'u profesör, \%16,67'si doçent, \%38,55'i doktor öğretim üyesi, \%4,16'sı araştırma görevlisi doktor, \%27,08'i araştırma görevlisi, \%1,05'i öğretim görevlisi doktor ve \%5,20'sinin öğretim görevlisi olduğu saptanmıştır. Gastronomi ve mutfak sanatları; lisans derecesine sahip 25 akademik personel, yüksek lisans derecesine sahip/devam eden 35 akademik personel ve doktora derecesine sahip sadece 1 doktor öğretim üyesi bulunmaktadır.

Eğitim alanları incelendiğinde turizm alanlarından sonra gıda mühendisliği programından mezun olan akademik personelin sayısının fazla olduğu görülmektedir. Toplam 38 akademik personelin lisans mezuniyeti gıda mühendisliği programıdır. Bu 38 akademik personelin $4^{\prime} \ddot{u}$ doçent, 27'si doktor öğretim üyesi, 4'ü araştırma görevlisi, 3’ü ise öğretim görevlisidir. Toplam 39 akademik personelin yüksek lisans mezuniyeti/devam eden eğitimi gıda mühendisliği programıdır. Bu 39 akademik personelin 1'i profesör, 4'ü doçent, 27'si doktor öğretim üyesi, 4'ü araştırma görevlisi, 3'ü ise öğretim görevlisidir. Toplam 34 akademik personelin doktora mezuniyeti/devam eden eğitimi gıda mühendisliği programıdır. Bu 34 akademik personelin 1'i profesör, 4'ü doçent, 25'i doktor öğretim üyesi, 1'i araştırma görevlisi, 3'ü ise öğretim görevlisidir. Toplam akademik personelin \%15,63'ünün gıda mühendisliği lisans derecesine sahip olduğu, $\% 16,05$ 'i gida mühendisliği yüksek lisans derecesine sahip olduğu/eğitimine devam ettiği ve \%14'ünün gıda mühendisliği doktora derecesine sahip olduğu/eğitimine devam ettiği belirlenmiştir.

Gastronomi ve mutfak sanatları programında görev yapan diğer akademik personelin eğitim alanlarının oldukça çeşitli ve birbirinden farklı alanlar olduğu tespit edilmiştir. Veteriner hekimlik, peyzaj mimarlığı, ortaöğretim fen ve matematik eğitimi, ticaret eğitimi, siyaset bilimi ve kamu yönetimi, Türkçe öğretmenliği, temel tıp bilimleri, biyoloji, biyomühendislik, enerji, zootekni, farmokoloji ve toksikoloji vb. olarak çeşitli alanlar göze çarpmaktadır. Akademik personelin eğitim alanlarının çeşitlilik göstermesinin, gastronomi ve mutfak sanatları eğitiminin geleceği açısından oldukça kaygı verici olduğunu söylemek mümkündür. Çünkü gastronomi ve mutfak sanatları programının temelini, mutfak uygulama dersleri oluşturmaktadır. Mutfak uygulamalarının alanında uzman kişiler tarafından eğitim mutfaklarında verilmemesi gastronomi ve mutfak sanatları eğitiminin temel amacından uzaklaşmasına sebep olabilir. Bu nedenle gastronomi ve mutfak sanatları eğitiminde alanında uzman kişilerin eğitim vermesinin eğitim kalitesini arttırmak adına önemli olduğu düşünülmektedir.

7. Akademik Turizm Eğitimi Arama Konferansı sonuç raporunda da gastronomi ve mutfak sanatları bölümlerindeki akademik personelin nicelik ve niteliğinde sorunlar yaşandığından bahsedilmektedir (Kozak ve Açıköz, 2015: 11). Sarışık ve Ceylan tarafından 2019 yılında yapılan çalışmada da gastronomi eğitimindeki mevcut sorunlar kısmında akademik personelin yetkinliğine değinilmiştir. İlgili bölümlerden mezun olmayan akademik personellerin gastronomi ve mutfak sanatları programındaki derslere hakim olmadıkları ifade edilmektedir. $\mathrm{Bu}$ yüzden programa yeni akademik personel ataması yapılırken eğitim alanlarının uygunluğu ve uzmanlık alanları göz önünde bulundurulabilir. Aynı zamanda gastronomi programlarında eğitim gören öğrenciler akademik kariyer yapmaları için yönlendirilebilir.

Özellikle teknolojik alanda yaşanan gelişmelerle birlikte yiyecek içecek sektöründe de birçok gelişmenin yaşandığını söylemek mümkündür. Bu gelişmeleri yakından takip etmek, eğitim ve uygulamalarda faydalanmak amacıyla gastronomi ve mutfak sanatları programında eğitim veren akademik personeller konferans, seminer, workshop, eğitim programları vb. etkinliklere katılabilirler ve gelişmeleri yakından takip edebilirler.

Kaliteli bir gastronomi eğitiminden bahsetmek için alanında uzman akademik personel kadar yeterli düzeyde donanıma sahip bir uygulama mutfağı da oldukça önem arz etmektedir (Görkem 
ve Sevim, 2016: 980). Çünkü gastronomi ve mutfak sanatları eğitimindeki en önemli detaylardan biri teorik ve uygulamalı eğitimin bir arada verilmesidir (Öney, 2016: 197; Alyakut ve Küçükkömürler, 2018: 825). Gastronomi ve mutfak sanatları eğitimi veren 40 kurumun web siteleri incelendiğinde $29^{\prime}$ unda uygulama mutfağ ${ }_{1}$ bulunduğu, $11^{\prime}$ inde ise uygulama mutfağ 1

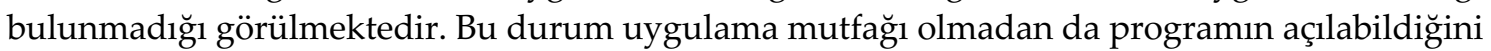
göstermektedir. Uygulama mutfağı bulunmayan 11 okuldan 4 'ü uygulama mutfağ için farklı mutfakları kullanmaktadır. Bu kurumlardan ikisi; uygulama oteli mutfağından, biri aynı üniversite bünyesindeki meslek yüksek okulu uygulama mutfağından, birisi ise il merkezinde yer alan Halk Eğitim Merkezi uygulama mutfağından yararlanmaktadır. Tütüncü tarafından 2019 yılında yapılan çalışmada da gastronomi ve mutfak sanatları programları kurulurken mutfak ile ilgili bir sınırlamanın olmadığından, mutfak olmadan da programın açlabildiğinden ve bu yüzden program sayısının her geçen gün arttığından bahsedilmektedir. Bu durumun önüne geçilmediği takdirde ise programdan mezun olanların birtakım sorunlar yaşayabileceği ifade edilmektedir. Bu yüzden eğitim kalitesini ve öğrenciler tarafından kurumun tercih edilebilirliğini arttırmak adına uygulama mutfağı bulunmayan kurumlar gerek üniversite desteği gerekse sponsor desteği ile uygulama mutfağı yapabilirler. Aynı zamanda uygulama mutfağı yetersiz olan kurumlar ise mutfaklarını geliştirmek adına projeler yürütebilir. İlgili kurum ve kuruluşlar üniversitelere bu konuda maddi destek sağlayabilirler.

- Yapılan bu çalışma devlet üniversiteleri ile sınırlandırılmıştır. Daha sonra yapılacak olan çalışmalarda vakıf üniversiteleri de araştırmaya dahil edilerek bu üniversitelerdeki gastronomi eğitimi veren programlar ve akademik personellere ilişkin bilgiler incelenerek karşılaştırılabilir.

- Meslek yüksek okullarındaki aşçılı programları ve bu okullardaki akademik personellere ilişkin bilgiler incelenerek daha kapsamlı bir çalışma yapılabilir. Bu programlardaki akademik personellerin uzmanlık alanları ve çalışma alanları incelenebilir.

- Gastronomi eğitiminin popüler hale gelmesi ile birlikte günümüzde birçok profesyonel eğitim veren mutfak akademileri açılmıştır. Yine daha sonraki çalışmalarda bu mutfak akademilerinde eğitim veren profesyonellerin eğitim durumları incelenebilir.

- Yapılan bu çalışma Mart 2020'ye kadar olan bilgileri içermektedir. Bu nedenle ilerleyen süreçte araştırma tekrar edilerek sonuçlar karşılaştırılabilir. Gastronomi ve mutfak sanatları programı ve akademik personellere ilişkin bilgilerin değişebileceği de göz önünde bulundurulmalıdır.

\section{KAYNAKÇA}

Akarsu, B. ve Akarsu, B. (2019). Bilimsel araştırma tasarımı nicel, nitel ve karma araştırma yaklaşımları. (1. Basım). İstanbul: Cinius Yayınları.

Akoğlu, A., Cansızoğlu, S., Orhan, N. ve Özdemir, Z. (2017). Gastronomi ve mutfak sanatları eğitimi alan öğrencilerin sektörde çalışmaya yönelik bakış açıları. Journal of Tourism and Gastronomy Studies, 5 (2), 146-159.

Aksoy, M. ve Şahin, A. (2018). Yiyecek içecek eğitiminde gastronomi ve mutfak sanatları ile kulinoloji programlarına dair bir karşılaştırma. Gazi Üniversitesi Sosyal Bilimler Dergisi, 5 (12), 720.

Akyurt, H. (2020). Yabancı öğrencilerin turizm eğitimi algılarının ve sorunlarının belirlenmesi: Giresun Üniversitesi üzerine bir araştırma. IBAD Sosyal Bilimler Dergisi, 6, 54-67. 
Allievi, F., Junttila, M., Vaisanen, K. and Taipale, M. M. H. (2019). Sustainable gastronomy education to achieves SDGs: supporting soft skills development and monitoring changes in students' awareness. e-Journal of University Lifelong Learning, 3 (1), 41-46.

Alyakut, Ö. ve Küçükkömürler, S. (2018). Gastronomi eğitimi alan üniversite öğrencilerinin mesleklerine yönelik metafor algılarının değerlendirilmesi. OPUS-Uluslararası Toplum Araştırmaları Dergisi, 9 (16), 823-852.

Arıkan, E., Sürücü, Ö. A. ve Arman, A. (2018). Yükseköğretim kurumlarındaki eğitim mutfaklarında karşılaşılan sorunlar ve çözüm önerileri. Journal of Tourism and Gastronomy Studies, 6 (2), 592-601.

Arslanhan, Y. ve Yaman, Z. Ö. (2019). Gastronomi ve mutfak sanatları lisans programlarının rakamsal gelişmeler açısından değerlendirilmesi. IV. Uluslararası Gastronomi Turizmi Araştırmaları Kongresi (19-21 Eylül 2019), Nevşehir: Nevşehir Hacı Bektaş Veli Üniversitesi, ss.776-779.

Aslan, Ş. ve Uyar, S. (2019). Araştırma yaklaşımlarının seçimi. Ş. Aslan (Ed). Sosyal bilimlerde araştırma yöntemleri nicel, nitel ve karma tasarımlar için bir rehber içinde (ss. 58-118). Konya: Eğitim Yayınevi.

Avcıkurt, C. ve Sarığlan, M. (2019). Gastronomi sosyolojisine genel bakış. C. Avcıkurt ve M. Sarıoğlan (Ed). Gastronomi olgusuna sosyolojik bakış içinde (ss.1-16). Ankara: Detay Yayıncllık.

Aydemir, D. A. ve Buyruk, L. (2019). Gastronomi ve mutfak sanatları öğrencilerinin aldıkları eğitim ile kariyer beklentileri ilişkisi: lisans öğrencilerine yönelik bir araştırma. IV. Uluslararası Gastronomi Turizmi Araştırmaları Kongresi (19-21 Eylül 2019), Nevşehir: Nevşehir Hacı Bektaş Veli Üniversitesi, ss.351-363.

Aymankuy, Y. ve Demirbulat, Ö. G. (2017). Türkiye'de lisans düzeyindeki gastronomi ve mutfak sanatları programlarının durum analizi. D. Bozok, C. Avcıkurt, M. Doğdubay, M. Sarığlan, G. K. Girgin (Ed). Gastronomi üzerine araştırmalar içinde (ss.223-236). Ankara: Detay Yayıncılık.

Babaç, E. ve Önçel, S. (2018). Anadolu Üniversitesi gastronomi ve mutfak sanatları bölümü öğrencilerinin özyeterliklerine yönelik nitel bir araştırma. Journal of Tourism and Gastronomy Studies, 6 (2), 282-298.

Beyter, N., Zıvalı, E. ve Yalçın, E. (2019). Türkiye'de lisans düzeyinde gastronomi eğitiminin değerlendirilmesi. IV. Uluslararası Gastronomi Turizmi Araştırmaları Kongresi (19-21 Eylül 2019), Nevşehir: Nevşehir Hacı Bektaş Veli Üniversitesi, ss.538-544.

Birdir, K. ve Kılıçhan, R. (2013). Mutfak şeflerinin mesleki eğitim düzeyleri ve yaşadıkları eğitim problemlerinin tespitine yönelik bir çalışma. 14. Ulusal Turizm Kongresi (05-08 Aralık 2013). Kayseri: Erciyes Üniversitesi Turizm Fakültesi, ss.615-635.

Boyraz, M., Çetin, A., Mutlu, H. ve Soybalı, H. H. (2018). Gastronomi ve mutfak sanatları öğrencilerinin workshop etkinlikleri algısının değerlendirilmesi: Afyon Kocatepe Üniversitesi örneği. Journal of Tourism and Gastronomy Studies, 6 (4), 132-149.

Brown, J. N. (2005). A brief history of culinary arts education in America. Journal of Hospitality $\mathcal{E}$ Tourism Education, 17 (4), 47-54.

Brown, J. N., Mao, Z. and Chesser, J. W. (2013). A comparison of learning outcomes in culinary education: recorded video vs. live demonstration. Journal of Hospitality \& Tourism Education, 25 (3), 103-109.

Bucak, T. ve Aracı, Ü. E. (2013). Türkiye'de gastronomi turizmi üzerine genel bir değerlendirme. Balıkesir Üniversitesi Sosyal Bilimler Enstitüsü Dergisi, 16 (30), 203-216. 
Bucak, T. ve Yiğit, S. (2018). Gastronomi eğitiminde profesyonel mutfak okullarının etkisi: İstanbul Mutfak Sanatları Akademisi (MSA) üzerine bir araştırma. Uluslararası Gastronomi Turizmi Araştırmaları Kongresi (20-22 Eylül 2018). Kocaeli: Kocaeli Üniversitesi, ss.809-822.

Büyüköztürk, Ş., Çakmak, E. K., Akgün, Ö. E., Karadeniz, Ş. ve Demirel, F. (2016). Bilimsel araştırma yöntemleri. (21. Basım). Ankara: Pegem Akademi.

Can, M. ve Çiftçi, B. (2019). Gastronomi ve mutfak sanatları bölümü ile aşçılık programı öğrencilerinin mesleki eğitim algısının öğrenme motivasyonu üzerine etkisi: ulusal aşçılık kampı Mengen örneği. Journal of Tourism and Gastronomy Studies, 7 (4), 2701-2717.

Cankül, D. (2019). Assessing the quality of gastronomy education: Turkey case. Elektronik Sosyal Bilimler Dergisi, 18 (70), 986-1002.

Cha, M. and Park, J. R. (2005). Knowledge and attitudes of food safety among hospitality and culinary students. Journal of Food Science and Nutrition, 10, 68-73.

Cheng, M., Ogbeide, G. C. A. and Hamouz, F. (2011). The development of culinary arts and food science into a new academic discipline-culinology. Journal of Culinary Science\&Tecnology, 9, 17-26.

Choi, J. W. and Kim, T. H. (2014). Comparative analysis of the educational service quality of domestic and foreign culinary schools using the kano model. Korean Journal Food \& Nutrition, 27 (4), 630-640.

Çarbuğa, Ü., Aydın, M., Sormaz, Ü. ve Yılmaz, M. (2018). Gastronomi eğitimi veren yükseköğretim kurumlarının uygulamalı meslek derslerinin değerlendirilmesi. ÇatalhöyükUluslararası Turizm ve Sosyal Araştırmalar Dergisi, 3, 14-23.

Çorbacı, A. K., Yılmaz, G. and Gültekin, S. (2018). An evaluation on culinary in Turkey. Global Conference on Education and Research- GLOCER 2018 (17-20 April 2018), USA: Las Vegas, p.53-55.

Çuhadar, M. ve Morçin, İ. (2020). Türkiye'de gastronomi turizmi ile ilgili çalışmaların bibliyometrik analizi. Journal of Recreation and Tourism Research, 7 (1), 92-106.

Davras, G. M. ve Davras, Ö. (2015). Gastronomi ve mutfak sanatları bölümü öğrencilerinin turizm sektöründe cinsiyet ayrımcilığıyla ilgili düşünceleri. Journal of Tourism Theory and Research, 1 (2), 86-96.

Denk, E. ve Koşan, A. (2017). Otel mutfak çalışanları mesleki eğitim seviyeleri ve kariyer hedeflerinin ölçülmesi: kış koridoru analizi. Yorum-Yönetim-Yöntem Uluslararası Yönetim-Ekonomi ve Felsefe Dergisi, 5 (1), 55-83.

Deveci, B., Türkmen, S. ve Avcıkurt, C. (2013). Kırsal turizm ile gastronomi turizmi ilişkisi: Bigadiç örneği. Uluslararası Sosyal ve Ekonomik Bilimler Dergisi, 3 (2), 29-34.

Deveci, B., Deveci, B., ve Avcıkurt, C. (2017). Yeme davranışı: gastronomi ve mutfak sanatları öğrencileri üzerine bir araştırma. Journal of Tourism and Gastronomy Studies, 5 (3), 118-134.

Deveci, B., Deveci, B., Karaman, N. ve Aymankuy, Y. (2017). Mutfak departmanına yönelik tutum: gastronomi ve mutfak sanatları öğrencileri üzerine bir araştırma. Akademik Bakış Uluslararası Hakemli Sosyal Bilimler Dergisi, 64, 717-732.

Deveci, B. ve Deveci, B. (2018). Vanilya ve vanilin ile ilgili bilgi düzeylerinin belirlenmesi: gastronomi ve mutfak sanatları öğrencileri üzerine bir araştırma. Journal of Tourism and Gastronomy Studies, 6 (Özel Sayı), 169-177. 
Doğancıll, O. S., Karaçar, E. ve Korkmaz, N. (2019). Gastronomi ve mutfak sanatları bölümü ile yiyecek içecek işletmeciliği bölümünün mevcut durumu üzerine bir değerlendirme. VIII. Uluslararası Meslek Yüksekokulları Sempozyumu-UMYOS (11-13 Haziran 2019), Sinop, ss.306-317.

Edens, D. (2011). Predictors of culinary students' satisfaction with learning. Journal of Hospitality $\mathcal{E}$ Tourism Education, 23 (3), 5-15.

Ekincek, S., Göde, M. Ö., Önçel, S. and Yolal, M. (2017). Gastronomy and culinary arts education in Turkey: department heads' perspective. Studia UBB Negotia, 62 (1), 23-43.

Gajic, M. (2015). Gastronomic tourism- a way of tourism in growth. Quaestus Multidisciplinary Journal, 6, 155-166.

Görkem, O. ve Sevim, B. (2011). Gastronomi turizmi ve Türkiye'de yükseköğretim düzeyinde mutfak eğitiminin genel görünümü. I. Uluslararası Turizm ve Otelcilik Sempozyumu (29 Eylül-01 Ekim 2011), Konya: Selçuk Üniversitesi, ss.73-83.

Görkem, O. ve Sevim, B. (2016). Gastronomi eğitiminde geç mi kalındı acele mi ediliyor? Elektronik Sosyal Bilimler Dergisi, 15 (58), 977-988.

Guzman, T. L. and Canizares, S. S. (2011). Gastronomy, tourism and destination differentiation: a case study in Spain. Review of Economics \& Finance, 2 (1), 63-72.

Güdek, M. ve Boylu, Y. (2017). Türkiye'de yükseköğretim düzeyinde gastronomi eğitimi alan öğrencilerin beklenti ve değerlendirmelerine yönelik bir araştırma. Journal of Tourism and Gastronomy Studies, 5 (4), 489-503.

Harrington, R. J., Mandabach, K. H., Thibodeaux, W. and Vanleeuwen, D. (2005). The institutionalization of culinary education. Journal of Culinary Science \& Technology, 4 (4), 31-49.

Hegarty, J. A. (2011). Achieving excellence by means of critical reflection and cultural imagination in culinary arts and gastronomy education. Journal of Culinary Science \& Technology, 9 (2), 55-65.

Hegarty, J. (2015). Culinary and hospitality teaching as a research-based profession. Research in Hospitality Management, 5 (2), 181-185.

Hertzman, J. and Ackerman, R. (2010). Evaluating quality in associate degree culinary arts programs. Quality Assurance in Education, 18 (3), 209-226.

Hertzman, J. L. and Mass, J. (2012). The value of culinary education: evaluating educational costs, job placement outcomes and satisfaction with value of associate degree culinary and baking arts program graduates. Journal of Culinary Science \& Technology, 10 (1), 53-74.

Hertzman, J. and Stefanelli, J. M. (2007). Quality indicators for associate degree culinary art programs: a survey of educators and industry chefs. Annual International CHRIE Conferance $\mathcal{E}$ Exposition (25-29 July 2007), USA: Dallas, Texas, p. 120-127.

http://gazi-universitesi.gazi.edu.tr/posts/view/title/2013/133-114908 [Erişim Tarihi: 15.05.2020].

Hu, M., Chen, L. and Lin, L. (2006). The comparative study of the culinary curriculum between Taiwan and USA. Journal of Culinary Science \& Technology, 5 (2-3), 93-107.

Karasar, N. (2020). Bilimsel Araştırma Yöntemi Kavramlar Illkeler Teknikler. (35. Basım). Ankara: Nobel Yayın Dağıtım.

King, W. R. and He, J. (2005). Understanding the role and methods of meta-analysis in IS research. Communications of the Association for Information Systems, 16, 665-686. 
Kivela, J. and Crotts, J. C. (2005). Gastronomy tourism: a meaningful travel market segment. Journal of Culinary Science \& Technology, 4 (2-3), 39-55.

Kozak, N. ve Açıköz, Z. (2015). Akademik Turizm Eğitimi Arama Konferansı sonuç raporu. İstanbul: Aktif Matbaa.

Kurnaz, A. (2019). Üniversite seçimini etkileyen faktörler: aşçllı ve gastronomi öğrencileri üzerine bir araştırma. Manas Sosyal Araştırmalar Dergisi, 8 (1), 612-627.

Kurnaz, A., Babür, T. E. ve Kurnaz, H. A. (2018). Gastronomi eğitiminde bir sosyal sorumluluk projesi örneği: Mengen Ulusal Aşçılık Kampı. OPUS-Uluslararası Toplum Araştırmaları Dergisi, 8 (Gençlik Araştırmaları Özel Sayıs1), 504-520.

Kurnaz, A., Kurnaz, H. A. ve Kılıç, B. (2014). Önlisans düzeyinde eğitim alan aşçılık programı öğrencilerinin mesleki tutumlarının belirlenmesi. Muğla Sıtkı Koçman Üniversitesi Sosyal Bilimler Enstitüsü Dergisi, 32, 41-61.

Lee, J. A. and Kim, C-H. (2013). A study on the current status and improvement plans for culinary education. The Korean Journal of Culinary Research, 19 (5), 280-295.

McKercher, B., Okumuş, F. and Okumuş, B. (2008). Food tourism as viable market segment: it's all how you cook the numbers. Journal of Travel \& Tourism Marketing, 25 (2), 137-148.

Miles, R. (2007). Culinary education: past, present practice and future direction. Annual International CHRIE Conferance \& Exposition (25-29 July 2007), USA: Dallas, Texas, p.266-271.

Murcott, A. (2019). Introducing the sociology of food \& eating. London: Bloomsbury Publishing Plc.

Öney, H. (2016). Gastronomi eğitimi üzerine bir değerlendirme. Selçuk Üniversitesi Sosyal Bilimler Enstitüsü Dergisi, 35, 193-203.

Özbay, G. (2019). Dünden bugüne gastronomi. M. Sarışık (Ed). Gastronomi bilimi içinde (ss.1-40). Ankara: Detay Yayıncılık.

Özdemir, N., Ak, S. ve Önçel, S. (2019). Lisans düzeyinde gastronomi ve mutfak sanatları eğitimi alan öğrencilerin kariyer yapma isteklerinin belirlenmesi. Uluslararası Sosyal Araştırmalar Dergisi, 12 (67), 947-956.

Özkaya, F. D., Sünnetçioğlu, S. ve Can, A. (2013). Sürdürülebilir gastronomi turizmi hareketliliğinde coğrafi işaretlemenin rolü. Journal of Tourism and Gastronomy Studies, 1 (1), 13-20.

Patah, M. O. R. A., Issa, Z. M. and Nor, K. M. (2009). Food safety attitude of culinary arts-based students in public and private higher learning institutions (IPT). International Education Studies, 2 (4), 168-178.

Santich, B. (2004). The study of gastronomy and its relevance to hospitality education and training. Hospitality Management, 23, 15-24.

Sarışık, M. ve Ceylan, V. (2019). Türkiye'de gastronomi eğitimi: mevcut durum, sorunları ve çözüm önerileri. IV. Uluslararası Gastronomi Turizmi Araştırmaları Kongresi (19-21 Eylül 2019), Nevşehir: Nevşehir Hacı Bektaş Veli Üniversitesi, ss.377-382.

Sarıoğlan, M. (2012). Türkiye'de gastronomi eğitiminin mevcut durumu ve geliştirilmesine yönelik bir model önerisi. IV. Uluslararası Türkiye Eğitim Araştırmaları Kongresi (04-07 Mayıs 2012), İstanbul: Yıldız Teknik Üniversitesi, ss.141-145.

Sarıoğlan, M. (2014a). A theoretical research on the constraints of development of gastronomy education in Turkey. Procedia-Social and Behavioral Sciences, 116, 260-264. 
Sarığlan, M. (2014b). New orientations in gastronomy education: molecular gastronomy. Procedia-Social and Behavioral Sciences, 143, 320-324.

Sarıoglan, M. (2018). A study related to evaluate the interaction between supply and demand within informal gastronomy education. Trakya Üniversitesi Sosyal Bilimler Dergisi, 20 (1), 267-283.

Sevim, B. ve Görkem, O. (2015). Gastronomi ve aşçlık programlarında gıda güvenliği donanım altyapısının değerlendirilmesi. Uluslararası Alanya İşletme Fakültesi Dergisi, 7 (1), 59-67.

Sönmez, V. ve Alacapınar, F. G. (2016). Örneklendirilmiş bilimsel araştırma yöntemleri. (4. Basım) Ankara: Anı Yayıncilık.

Sünnetçioğlu, A., Yalçınkaya, P., Olcay, M. ve Mercan, Ş. O. (2017). Turizm alanında yazılmış olan gastronomiye ilişkin tezlerin bibliyometrik profili. Journal of Tourism and Gastronomy Studies, 5 (Özel Sayı 2), 345-354.

Şengül, S. (2019). Gastronomi eğitimi ve gastronomide kariyer. M. Sarışık (Ed). Tüm yönleriyle gastronomi bilimi içinde (ss.169-186). Ankara: Detay Yayıncılık.

Tütüncü, Ö. (2019). Lisans eğitiminde mutfak zanaatları ve gastronomi. Anatolia: Turizm Araştırmaları Dergisi, 30 (1), 93-97.

Ülker, M. ve Kılıçhan, R. (2017). Gastronomi ve mutfak sanatları alanındaki akademisyenlerin örgütsel bağlllıklarının iş tatminleri üzerindeki etkisi. Yönetim, Ekonomi ve Pazarlama Araştırmaları Dergisi, 1 (4), 13-30.

Yaman, Z. Ö. ve Bulduk, S. (2019). Gastronomi ve mutfak sanatları eğitiminin kalite göstergeleri açısından değerlendirilmesi. Business \& Management Studies: An International Journal, 7 (5), 27702804.

Yazıcıoğlu, İ. ve Özata, E. (2017). Gastronomi ve mutfak sanatları bölümü öğrencilerinin ders programı algılarının akademik başarılar üzerine etkisi. Journal of Tourism and Gastronmy Studies, $5(4), 17-32$.

Yazıcıoğlu, İ. ve Özata, E. (2018). Gastronomi ve mutfak sanatları bölümü öğretim elemanlarının ders programlarına yönelik algıları. IV. Uluslararası Kültür ve Medeniyet Kongresi (21-23 Aralık 2018), Mardin, ss.65-74.

Yıldız, M. ve Aslan, Z. (2019). Yiyecek-içecek alanında eğitim alan öğrencilerin mesleklerine bakış açları. Journal of Tourism and Gastronomy Studies, 7 (2), 1124-1141.

Yılmaz, G. (2019). Türkiye'de ortaöğretim ve yükseköğretim düzeyinde gastronomi eğitiminin değerlendirilmesi. Turizm Akademik Dergisi, 6 (1), 229-248.

Yılmaz, H. ve Çemrek, F. (2019). Assçllık programı ile gastronomi bölümünde okuyan kadın öğrencilerin aşçıllk mesleğine yönelik tutumları: Afyon Kocatepe Üniversitesi Örneği. Journal of Gastronomy Hospitality and Travel, 2 (2), 141-156.

Yükseköğretim Akademik Arama Motoru (2019). https://akademik.yok.gov.tr/AkademikArama/ [Erişim Tarihi: 12.03.2020].

Yükseköğretim Program Atlası (2019). https://yokatlas.yok.gov.tr/ [Erişim Tarihi: 12.03.2020].

Yükseköğretim Kurulu (2019). https://www.yok.gov.tr/universiteler/universitelerimiz [Erişim Tarihi: 12.03.2020].

Zopiatis, A., Theodosiou, P. and Constanti, P. (2014). Quality and satisfaction with culinary education: evidence from Cyprus. Journal of Hospitality \& Tourism Education, 26, 87-98. 